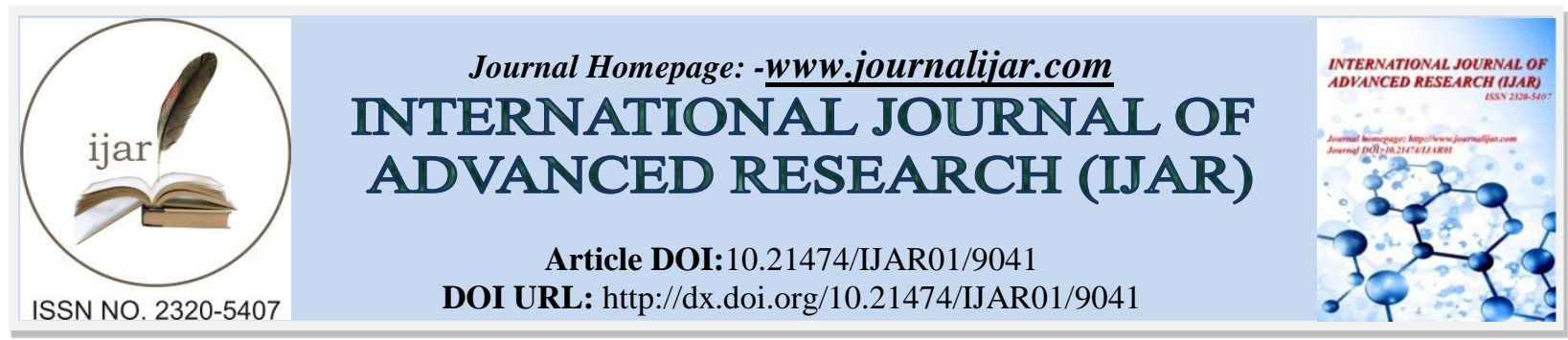

RESEARCH ARTICLE

\title{
SELECTION AND EVALUATION ON THE FATHER ANCESTORS GENOTYPE AND MOTHER ANCESTORS PRODUCTIVE INDICES OF IMPORTED FLECKVIEH SIMMENTAL AND SCHWYZ BREED COMBINED- PRODUCTIVE IMPROVER BULLS.
}

\section{Dosmukhammedova Mukhayyo Khusnitdinovna ${ }^{1}$, Nosirov Ubaydulla Nasrullaevich ${ }^{2}$, Khodjaev Ulugkhuja Turaboevich $^{3}$ and Mavlonov Shakhriddin Eshpulat Ugli ${ }^{4}$.}

1. Doctor of Agricultural Sciences, Dotsent of Department General Zootechnics, Tashkent State Agrarian University, Tashkent, Uzbekistan.

2. Doctor of Agricultural Sciences, Professor of Department General Zootechnics, Tashkent State Agrarian University, Tashkent, Uzbekistan.

3. Independent Researcher of Department General Zootechnics, Tashkent State Agararian University, Tashkent, Uzbekistan.

4. Third Course Bachelor Student the Faculty Zootechnics and Sericulture, Tashkent State Agrarian University, Tashkent, Uzbekistan.

\section{Manuscript Info}

(..........................

Manuscript History

Received: 10 March 2019

Final Accepted: 12 April 2019

Published: May 2019

Key words:-

Fleckvieh Simmental, Schwyz improver

and improver leader bulls, artificial

insemination, selection and sorting,

combined- productive and to improve

of local cattle.

\section{Abstract}

In the article current value of bulls improver on the genotype of father, on productive index of mother and using them in the system for natural insemination cattle have been introduced.

Copy Right, IJAR, 2019,. All rights reserved.

\section{Introduction:-}

The insemination of combined- productive breed and improvement of local herds have been identified and zoned by selection plans in the piedmont areas. During the spring and summer months, livestock is maintained in natural pastures, while preserving and feeding on farms in large piedmont areas of the country. These conditions are applied more effectively in the production, feeding and distributing combined-productive cattle. Until now, inseminated cows in these areas have been characterized by low productivity and have not responded to human needs [1].

In particular, the milk yield of the livestock of these genus those inseminating in Andijan, Namangan, Tashkent, Syrdarya, Jizzakh, Kashkadarya and Surkhandarya regions' farmstead was average 970-1800 kilograms. These productivity indicators are very low, and the use of genus that improver bulls is an urgent task to develop the herds rapidly.

\section{Materials and Method:-}

The object of the research were combined-productive improver Fleckvieh Simmental and Schwyz breed bulls and their selection measures to improve inseminating local cattle in the piedmont area of the republic.

In research methods, bull breeding techniques to breed local breeds and blending methods red breed herds with the leader bulls and local improver bulls with pure breeding were used to select breeds and bulls were selected based on 
the ancestral genotype and parent productivity indices. In the selection of Fleckvieh Simmental supplementary bulls, modern selection and sampling methods were used. Improving bulls are used for fertilizer breeding of pure breed Fleckvieh Simmental herds, while improving bulls are used in artificial insemination systems for breeding cattle breeding in their fertilized areas. As a result of 60 years of selection experiments, until the independence of Uzbekistan, breeding red cattle with $2500-3000 \mathrm{~kg}$ of milk in Jizzakh, Kashkadarya and Syrdarya foothill regions and creation of herds with 4000-4500 kg of milk at the state farm "Savay" of the Kurgan Tepa district of Andijan region were known that the methods of achieving these indicators were introduced. For this purpose, Fleckvieh Simmental breeders that are improvers were imported apply the in proper quantities resulted in good effects [3, 4].

\section{Result and Discussion:-}

Studies have also aimed at evaluating and selecting the genotype, individual characteristics and sperm productivity of Fleckvieh Simmental and Schwyz breeding bulls imported for the purpose of improving the productivity of the fertilizer zones and local herd in addition, where modern selection methods have been used. It is known from the selection practices that developed countries are extensively used in artificial insemination only the bulls, which are evaluated only by their quality or genotype.

We draw great attention to the application of improver bulls factors and implement artificial system extensively as well as improve selection and pedigree in current state of cattle breeding of the republic. First of all, the bulls have been described by new methods for the genotype of their ancestors in the production of high-quality sperms for importing and artificial insemination, which have been successfully formulated their improvement leader and group of improvement bulls (Table I).

According to the data of the table, the combined bulls are characterized by high productivity and nurturing qualities. However, the combined-breed bulls distinguished among the groups differ in their superiority. The choice of bull groups is to improve the use of bulls in pure breeding and red-breeding herds or pure breeding, using bulls in improving groups to cross domestic livestock in their respective areas. The leading Fleckvieh Simmental breed bulls have increased their breed to 1142 kilograms, milk fat $48,7 \mathrm{~kg}$ and milk protein 37,7 kilograms to their peers [2; 5]. In particular, the productivity index (RPI) was 130,3\%; the pedigree index was 126,3; the exterior (RZE) 101,0; and the breeding index (RMS) was 102,3\%.

These indicators were $919,6 \mathrm{~kg}, 28,2 \mathrm{~kg}, 25,2 \mathrm{~kg}, 118,6 \%, 126,0 \%, 111,8 \%$ and 103,0\%, in Schwyz bulls respectively.

Table I:-Combined-productive genotype and quality indicator indices of parental bulls of Fleckvieh Simmental and Schwyz breed

\begin{tabular}{|c|c|c|c|c|}
\hline \multirow[t]{2}{*}{ Indicators } & \multicolumn{2}{|c|}{ Fleckvieh Simmental breed $(n=6)$} & \multicolumn{2}{|c|}{ Schwyz breed $(n=9)$} \\
\hline & $\mathbf{S} \pm \mathbf{X}$ & $\mathrm{Cv}$ & $\mathbf{S} \pm \mathbf{X}$ & $\mathrm{Cv}$ \\
\hline \multicolumn{5}{|c|}{ Improving leader bulls } \\
\hline Superior milk yield of the offspring, kg & $+1142,7 \pm 81,1$ & 12,3 & $+919,6 \pm 213,5$ & 51,9 \\
\hline The superiority of milk fat, $\mathrm{kg}$ & $+48,7 \pm 5,0$ & 18,0 & $+28,2 \pm 6,7$ & 52,2 \\
\hline The superiority of milk protein, $\mathrm{kg}$ & $+37,7 \pm 1,5$ & 6,9 & $+25,2 \pm 2,4$ & 20,9 \\
\hline Productivity Index (RZM),\% & $130,3 \pm 1,9$ & 2,6 & $118,6 \pm 2,4$ & 4,6 \\
\hline Pedigreeindex (RZG), \% & $126,3 \pm 0,7$ & 1,0 & $126,0 \pm 57,2$ & 7,8 \\
\hline Exterior index (RZE), \% & $101,0 \pm 4,0$ & 6,9 & $111,8 \pm 2,1$ & 4,1 \\
\hline Insemination index (RZN), \% & $102,3 \pm 7,7$ & 13,0 & $103,0 \pm 5,9$ & 12,8 \\
\hline \multicolumn{5}{|c|}{ Improving bulls group } \\
\hline Superior milk yield of the offspring, kg & $+854,0 \pm 166,6$ & 33,8 & $+309,7 \pm 42,9$ & 27,7 \\
\hline The superiority of milk fat, $\mathrm{kg}$ & $+20,7 \pm 5,8$ & 48,2 & $+12,3 \pm 2,0$ & 31,9 \\
\hline The superiority of milk protein, $\mathrm{kg}$ & $+25,0 \pm 4,0$ & 27,9 & $+12,7 \pm 2,8$ & 43,1 \\
\hline Productivity index (RZM), \% & $116,0 \pm 3,2$ & 4,7 & $109,5 \pm 1,7$ & 3,0 \\
\hline Pedigree index (RZG), \% & $104,7 \pm 10,7$ & 17,7 & $110,7 \pm 1,7$ & 2,6 \\
\hline Exterior index (RZE), \% & $103,3 \pm 2,5$ & 4,3 & $108,7 \pm 5,1$ & 9,3 \\
\hline Insemination index (RZN), \% & $109,0 \pm 50,2$ & 6,5 & $108,0 \pm 4,5$ & 8,4 \\
\hline
\end{tabular}

The main ancestors of imported bulls have high proponent attributes that have passed on generations to a higher degree. Therefore, the imported bulls are of the category of enhancers. The new generations that can be received of 
them have high productive qualities and produce productive herds In the group of improved bulls, some bulls are characterized by superfluous nurture and productive qualities. Specifically, Fleckvieh Simmental breeders of the Xerlizan system, nicknamed "Xeroz", increased milk yield to $1263 \mathrm{~kg}$, milk fat $55 \mathrm{~kg}$ and milk protein by 41 kilograms to parental peers. Productivity index is $128 \%$, pedigree index is 134, and exterior index is $108 \%$. In the bull which name was "Vaska" Schwyz breed of Vaseli system the indicators those above-mentioned were $1814 \mathrm{~kg}$, $56,34 \mathrm{~kg}, 133 \%, 129$ and $115 \%$, respectively. Selected breeders and breeding bulls selected for parent genetics were found to be classified on ancestral productive index.

The live mass of the nicknamed bull Vaska DE52699617 is 410kilogram,class elite record, and mother's milk yield is 1-12086-3,69-365. That is, their mothers are characterized by the high yield and productive characteristics as well as producing bull cows group (Table II).

Table II:-The productive index of the mother ancestors' of Fleckvieh Simmental and Schwyz breed bulls

\begin{tabular}{|c|c|c|c|c|}
\hline \multirow{2}{*}{ Indicators } & \multicolumn{2}{|c|}{ Fleckvieh Simmental breed $(n=6)$} & \multicolumn{2}{|c|}{ Schwyz breed $(n=9)$} \\
\hline & $\mathbf{S} \pm \mathbf{X}$ & $\mathrm{Cv}$ & $\mathbf{S} \pm \mathbf{X}$ & $\mathrm{Cv}$ \\
\hline \multicolumn{5}{|c|}{ Improving leader bulls group } \\
\hline Milk yield during lactation, $\mathrm{kg}$ & $11563,7 \pm 357,1$ & 5,3 & $11232,4 \pm 215,5$ & 4,3 \\
\hline Fat content in milk, $\%$ & $3,88 \pm 0,1$ & 3,7 & $4,12 \pm 0,2$ & 11,3 \\
\hline The content of protein in milk, $\%$ & $3,56 \pm 0,0$ & 2,1 & $3,61 \pm 0,0$ & 1,9 \\
\hline Milk fat content, $\mathrm{kg}$ & $445,0 \pm 9,3$ & 3,6 & $463,0 \pm 13,1$ & 6,3 \\
\hline Milk protein content, $\mathrm{kg}$ & $408,0 \pm 16,3$ & 6,9 & $406,0 \pm 7,8$ & 4,3 \\
\hline \multicolumn{5}{|c|}{ Improving bulls group } \\
\hline $\begin{array}{l}\text { Quantity of milk yield during lactation, } \\
\mathrm{kg}\end{array}$ & $9877,3 \pm 508,3$ & 8,9 & $11525,0 \pm 408,1$ & 7,1 \\
\hline Fat content in milk, \% & $4,28 \pm 0,2$ & 6,6 & $4,20 \pm 0,1$ & 6,4 \\
\hline The content of proteins in milk, $\%$ & $3,56 \pm 0,1$ & 3,1 & $3,73 \pm 0,1$ & 4,6 \\
\hline Milk fat amount, $\mathrm{kg}$ & $422,3 \pm 16,7$ & 6,8 & $484,0 \pm 0,7$ & 0,3 \\
\hline Milk protein content, $\mathrm{kg}$ & $352,0 \pm 15,3$ & 7,5 & $429,5 \pm 14,8$ & 6,9 \\
\hline
\end{tabular}

The mothers' of the Fleckvieh Simmental breeder bulls were found to have an average milk yield of $11463,7 \mathrm{~kg}$, fat $3,88 \%$, protein content $3,56 \%$, dairy butter $445 \mathrm{~kg}$, milk protein $408 \mathrm{~kg}$, these indicators were $11232,4 \mathrm{~kg}, 4,12 \%$, $3,61 \%, 463 \mathrm{~kg}$ and 406 kilograms, in Schwyz bulls respectively. The mothers in the improvement group are characterized by their productivity and, especially, the high fat content. For example, mothers' milk yield in Schwyz breed bulls is 11525 kilograms, the amount of fat is 4,20\%. Fleckvieh Simmental milk was slightly lower, but the fat content was 4,28 percent. The mother, of the bull called "Khimon", in the Fleckvieh Simmental, fat content was $5,02 \%$, milk yield was $11938 \mathrm{~kg}$ and milk fat increased to 599 kilograms.

These combined-productive breeders differ significantly from the high protein content in milk yielding. The quality of cows fed in pasture conditions is very useful in the preparation of cheese. It is acceptable to fertilize Fleckvieh Simmental and Schwyz breeding in piedmont areas and produce 5-7 thousand kilograms of pure fat and protein milk. However, some farmers have been involved in intensive irrigated agriculture.. In these areas, Fleckvieh Simmental and Schwyz breed can not be competitors in black and red-motley Holstein breeds on productivity.

It is permissible for each breed to control fertilization in their zonalized and conditioned areas.

\section{Conclusion:-}

Fertilize combined-productive breeds in their zonalized regions and improve their herds. Widespread introduction of artificial insemination systems in all categories of farms, especially in the piedmont area, where Fleckvieh and Schwyz breed sperms are widely used in breeding. Evaluate and select of improver Fleckvieh Simmental and Schwyz breeds by their genetic qualities and parent ancestral productivity index to import and export.

\section{References:-}

1. Decree of the President of the Republic of Uzbekistan of October 9, 2017 "On measures of legal profit and rights defense of farmers, owners of households and plots, radical improvement of efficient usage of agricultural fields system” PD №5199, Laws collection of the Republic of Uzbekistan, 2017, №12 (In Uzbek) 
2. Fuerst-Waltl B., Schwarzenbacher H, Perner C, Sölkner J. Effects of age and environmental factors on semen production and semen quality of Austrian Simmental bulls// Animal Reproduction Science. 2006, Vol.95 (1-2). P.27-37. (In English)

3. Nasirov T. Usmanov O. RSA Genetic in Uzbekistan. Die genetische Effizienz von RSA - Vchwarsbunton Kiihcn in Uzbekistan. RSA Magazin Rindersucht Verbund Sachsen-Anhalt OG. Sammer, 2008, p. 34-35. (In Deutch)

4. Nosirov U.N. et al. Classical and modern selection methods in livestock breeding. Tashkent. 2008.

5. Nosirov U.N. Factors of livestock development in Uzbekistan. SML-ASIA. 2011. -195 p. (In Uzbek). 